\title{
Chemical Characteristics of Rainwater in Sumatera, Indonesia, during 2001-2010
}

\author{
Tuti Budiwati, Wiwiek Setyawati, and Dyah Aries Tanti \\ The Center for Atmospheric Science and Technology-LAPAN, Jalan Dr. Djundjunan 133, Bandung 40173, Indonesia \\ Correspondence should be addressed to Tuti Budiwati; tuti_lapan@yahoo.com
}

Received 6 December 2015; Revised 29 February 2016; Accepted 28 March 2016

Academic Editor: Panagiotis Nastos

Copyright ( 2016 Tuti Budiwati et al. This is an open access article distributed under the Creative Commons Attribution License, which permits unrestricted use, distribution, and reproduction in any medium, provided the original work is properly cited.

\begin{abstract}
The chemical composition of acid deposition shows that ammonium and chloride concentrations as the indicators of forest fires were higher than sulfate and nitrate in Sumatera areas such as Medan, Lampung, Palembang, and Kototabang. Chloride had higher concentration than sodium $\left(\mathrm{Na}^{+}\right.$sea originated) with the ratio value of $\mathrm{Cl}^{-} / \mathrm{Na}^{+}>1.16$ found in Medan and Palembang. Ionic compositions from the lowest to the highest concentration in Kototabang were $\mathrm{H}^{+}>\mathrm{Cl}^{-}>\mathrm{Na}^{+}>\mathrm{NH}_{4}^{+}>\mathrm{nss}^{-} \mathrm{Ca}^{2+}>\mathrm{K}^{+}>\mathrm{NO}_{3}{ }^{-}>$

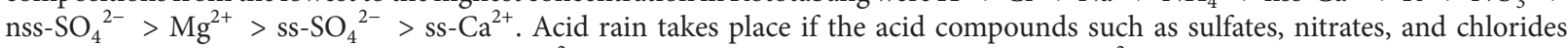
dominate. If the ratio value of $\mathrm{NO}_{3}{ }^{-} /\left(\mathrm{nss}-\mathrm{SO}_{4}{ }^{2-}+\mathrm{NO}_{3}{ }^{-}\right)<0.5$ then it indicates that nss- $\mathrm{SO}_{4}{ }^{2-}$ is higher than $\mathrm{NO}_{3}{ }^{-}$. Between 2001 and 2010 it was found that the frequency value of $\mathrm{NO}_{3}{ }^{-} /\left(\right.$nss- $\left.\mathrm{SO}_{4}{ }^{2-}+\mathrm{NO}_{3}{ }^{-}\right)<0.5$ was $97 \%$ from annual mean of 34 pieces of data in Medan, Kototabang, Lampung, and Palembang. Forest fires influence was more dominant than anthropogenic activities in Kototabang, Palembang and Lampung, except in Medan. It showed that ammonium was higher than $\mathrm{NO}_{3}{ }^{-}$content if the ratio value of $\mathrm{NO}_{3}{ }^{-} /\left(\mathrm{NH}_{4}{ }^{+}+\mathrm{NO}_{3}{ }^{-}\right)<0.5$ was $62 \%$. For the period 2001-2010 the frequency value of $\mathrm{NO}_{3}{ }^{-} /\left(\mathrm{NH}_{4}{ }^{+}+\mathrm{NO}_{3}{ }^{-}\right)<0.5$ was $74 \%$ from total 34 annual mean pieces of data in four locations, that is, Medan, Kototabang, Palembang, and Lampung.
\end{abstract}

\section{Introduction}

Frequent forest fires and increasing consumption of fossil fuel as a result of population growth in Sumatera, Indonesia, have led to air quality degradation as well as acid rain occurrence. Rainwater chemical composition analyses can answer environmental problems occurring from the air quality condition. The values vary from one to other locations because of local influence. If the emission source is affected by anthropogenic activities, rainwater will become acid because of the impact of acid gases $\mathrm{SO}_{2}$ and $\mathrm{NO}_{2}$ and also base gas $\mathrm{NH}_{3}$ [1]. In microscale or local scale, air pollution will just affect local air quality within a relatively limited area, for example, air pollution generated by dust. On the other hand in mesoscale or regional scale, air pollution affects larger area such as rain [2] and the pollutants are relatively persistent in the atmosphere and can be transported simultaneously with air mass to long distance [3].

Urban transportation is a potential source of emissions, such as gaseous $\mathrm{SO}_{2}, \mathrm{NO}_{x}, \mathrm{CO}, \mathrm{CO}_{2}, \mathrm{CH}_{4}, \mathrm{NMHC}$, and $\mathrm{O}_{3}$, a product of the photochemical process, and also particles.
Active volcanoes are sources of sulfuric gases such as $\mathrm{H}_{2} \mathrm{~S}$ and $\mathrm{SO}_{2}$ and also $\mathrm{HCl}$ and $\mathrm{HF}$ that can affect surrounding areas. $\mathrm{SO}_{2}, \mathrm{NO}_{2}$, and particulate aerosol are abundant products of forest and land fires in Sumatera such as North Sumatera, Riau, Jambi, and South Sumatera. These gases together with particulate aerosols will be removed from the atmosphere through the wet deposition that can lead to acid rain. The wet deposition is a washing process where pollutants (gases and particles) are absorbed by rain components (water drops, ice particles) and precipitated to the surface during rain. This process consists of cloud drops formation by pollutant through washout and raindrops formation through rainout. The washout is a pollutant cleaning process inside the clouds through the condensation of nuclei formation that will finally become raindrops. The rainout is a pollutant cleaning process through dissolving pollutant particles by rainwater or snow [4]. Wet deposition consists of $75 \%$ washout and $25 \%$ rainout $[4,5]$.

Gases emitted by urban transportation and industries and also volcanoes around the western coast of Sumatera will give mesoscale impact to rainwater chemical components in 
surrounding areas. The wind will disperse the clouds and the pollutant to every direction. The highest increase parameter in Europe is sulfate; meanwhile in China it is nitrate. Transboundary pollutant also occurred in Japan in 20032005 , resulting in the increase of the concentration of sulfate $\left(\mathrm{SO}_{4}{ }^{2-}\right)$ originated from Asia and passed through the long distant above the East Asian Pacific rim [6]. In Tirupati, India, there were high correlations between $\mathrm{Ca}^{2+}$ (calcium) and $\mathrm{SO}_{4}{ }^{2-}$ (sulfate) and between $\mathrm{Ca}^{2+}$ and $\mathrm{NO}_{3}{ }^{-}$with correlation coefficients $(r)$ of 0.92 and 0.90 , respectively [7]. Strong correlations were also found between $\mathrm{Mg}^{2+}$ (magnesium) and $\mathrm{SO}_{4}{ }^{2-}$ (sulfate) and between $\mathrm{Mg}^{2+}$ and $\mathrm{NO}_{3}{ }^{-}$with $r=0.83$ and 0.77 , respectively. The fact showed that rainwater ions compositions were influenced more strongly by terrestrial sources [7] than anthropogenic and sea sources. A study by Budiwati et al. [8] showed that air quality in Pontianak city was degraded as a result of the forest fire in West Kalimantan in 2006. It also led to rainwater $\mathrm{pH}$ decrease at the end of 2006 until the beginning of 2007. During September to December 2006, the average $\mathrm{pH}$ value was 5.51 (5.36-5.62), and during January to July 2007, the average $\mathrm{pH}$ value was 5.11 (4.785.85).

Sumatera regions are divided into the geographic and agroecological map as described by Scholz [9] (Figure 1). Bukit Barisan mountains lie in western part of Sumatera Island, extending from the Northernmost Aceh province to Southernmost Lampung Province. In the east side of Bukit Barisan mountains lie flammable peatland zones. Most of the peat swamp forests are found in eastern lowlands of Sumatera coast. Long dry seasons followed by land clearing for agricultural purposes by burning lead to the frequent forest and land fires in Sumatera every year. North Sumatera is a densely populated region with Medan as its capital city, characterised by heavy transportations among other capital cities in Sumatera. Because acid rain or wet deposition problems were created by air quality degradation in Sumatera as a result of atmospheric pollutants cleaning process, therefore it was important to carry out an assessment of variability and distribution of wet deposition during 2001-2010 in Sumatera. The analysis of rainwater chemical compositions in Sumatera can explain the origin of dominant sources.

\section{Methods}

Statistical analysis of $\mathrm{pH}$ frequency distribution was carried out to study acid rain events in four different cities in Sumatera, Indonesia, that is, Medan, Kototabang, Lampung, and Palembang (Figure 2). Rainwater chemical data were obtained from the Agency for Meteorology, Climatology and Geophysics (BMKG) during $10 \mathrm{y}$ from 2001 to 2010. The data had been passed through QA/QC according to the World Meteorology Organization (WMO) guidelines. Weekly sampling of rainwaters was carried out according to the WMO guidelines. Anions and cations in rainwater samples were analyzed by using Ion Chromatography (Dionex, type ICS 1600). The $\mathrm{pH}$ of rainwater samples was measured by using a $\mathrm{pH}$ meter (Thermo 3 star) using glass electrode, standardized with $\mathrm{pH} 4$ and seven reference buffers. Rainwater chemistry

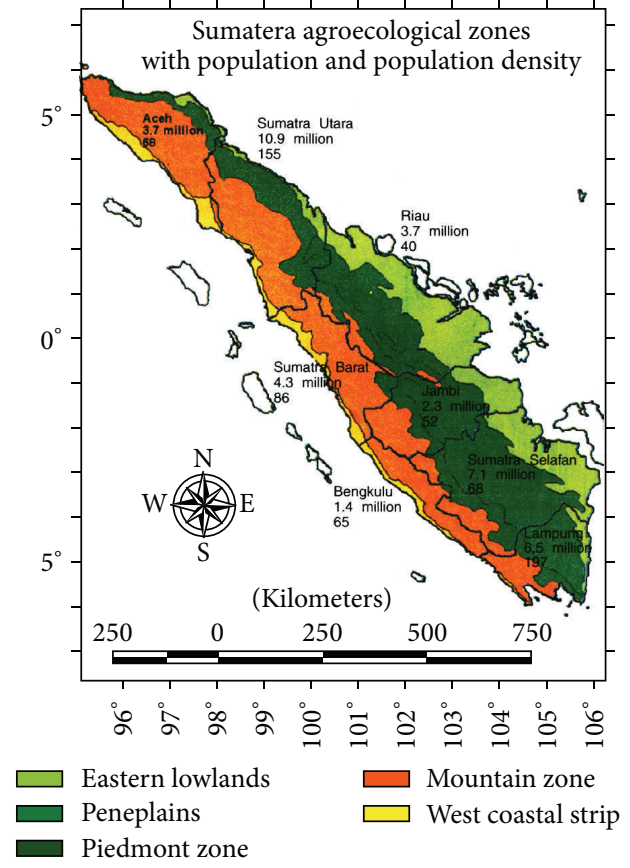

Figure 1: Agroecological zones, provinces, and population of Sumatera, Indonesia [9].

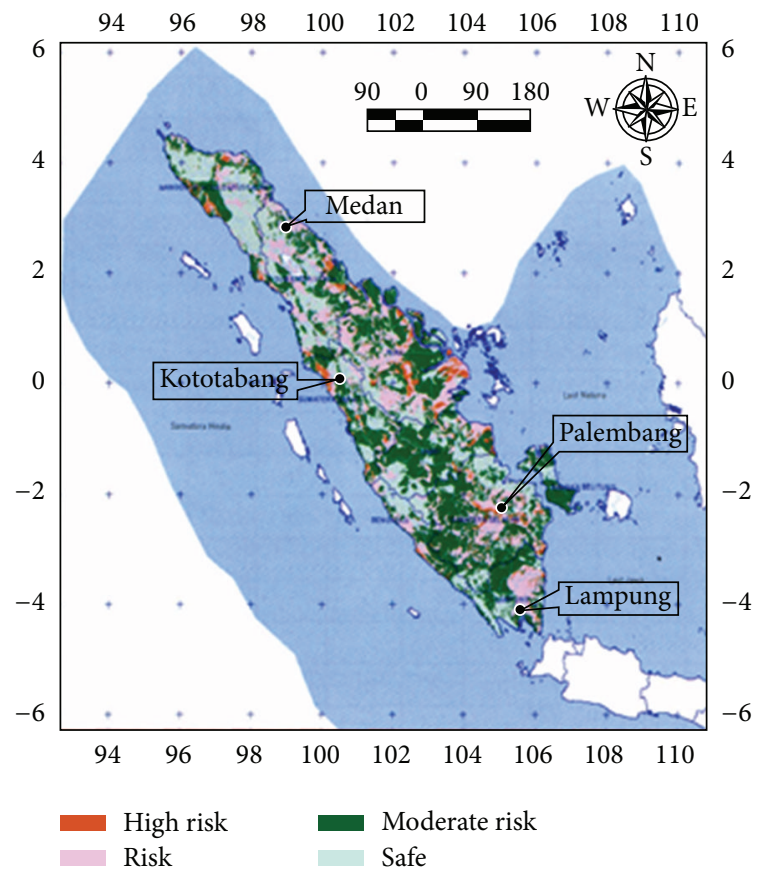

FIGURE 2: Wet deposition monitoring locations and map of forest and land fire risk locations in Sumatera in 2007 (Source: [14]).

data consist of the volume-weighted monthly mean of $\mathrm{pH}$, $\mathrm{SO}_{4}{ }^{2-}, \mathrm{NO}_{3}{ }^{-}, \mathrm{Cl}^{-}, \mathrm{NH}_{4}{ }^{+}, \mathrm{Ca}^{2+}, \mathrm{K}^{+}, \mathrm{Na}^{+}$, and $\mathrm{Mg}^{2+}$ in the unit of $\mu \mathrm{mol} / \mathrm{L}$. Hydrogen ion concentration was calculated from the measured $\mathrm{pH}[10,11]$. The volume-weighted mean 
concentrations of the main ionic components in rainwater samples $(r)$ were calculated by using

$$
r=\frac{\sum_{i=1}^{n} X_{i} \cdot Y_{i}}{\sum_{i=1}^{n} Y_{i}}
$$

where $X_{i}$ is valid concentration of ions for sample $i(\mu \mathrm{mol} / \mathrm{L})$. $Y_{i}$ is precipitation amount for the same sample $i$ with valid concentration $(\mathrm{mm}), n$ is the number of rainy days. $r$ is volume-weighted mean concentration (monthly).

Concentrations of non-sea salt sulfate $\left(\mathrm{nss}-\mathrm{SO}_{4}{ }^{2-}\right.$ ) and non-sea salt calcium (nss-Ca ${ }^{2+}$ ) were calculated by using (2) and (3), respectively $[10,11]$. The concentration unit was in $\mu \mathrm{mol} / \mathrm{L}$ :

$$
\begin{aligned}
\text { nss- }\left[\mathrm{SO}_{4}{ }^{2-}\right] & =\left[\mathrm{SO}_{4}{ }^{2-}\right]-0.06028\left[\mathrm{Na}^{+}\right] \\
\text {nss- }\left[\mathrm{Ca}^{2+}\right] & =\mathrm{Ca}^{2+}-0.02161\left[\mathrm{Na}^{+}\right]
\end{aligned}
$$

The concentrations of $\mathrm{SO}_{4}{ }^{2-}, \mathrm{Ca}^{2+}$, and $\mathrm{Na}^{+}$were the concentration of ions contents in rainwater. Concentrations of nonsea salt sulfate (nss- $\mathrm{SO}_{4}{ }^{2-}$ ) and non-sea salt calcium (nss$\mathrm{Ca}^{2+}$ ) are the difference between concentration of $\mathrm{SO}_{4}{ }^{2-}$ and $\mathrm{Ca}^{2+}$ in rainwater and concentration of $\mathrm{SO}_{4}{ }^{2-}$ and $\mathrm{Ca}^{2+}$ in sea salt.

The assessment of rainwater chemistry characteristics was carried out to study the influencing factors: anthropogenic or forest fires. Gas samples and particles were also used in the research by using filter pack for seven consecutive $\mathrm{d}$ starting from September 21, 2012, to September 28, 2012, in National Institute for Aeronautics and Space (LAPAN) station located in Kototabang. Filter pack comprises four stack holders with four filters. First filter (F0: Teflon PTFE) was used to capture aerosol particle, the second filter (F1: polyamide) was used to obtain $\mathrm{HNO}_{3}$, and other gases such as $\mathrm{HCl}, \mathrm{SO}_{2}$, and $\mathrm{NH}_{3}$ passed through the third filter (F3: cellulose filled with $\mathrm{K}_{2} \mathrm{CO}_{3}$ ) where $\mathrm{HCl}$ and $\mathrm{SO}_{2}$ were captured. Fourth filter (F3: cellulose filter with phosphoric acid) captured $\mathrm{NH}_{3}$. The diameter size of F0, F1, F2, and F3 was $47 \mathrm{~mm}$. The air was sucked with flow rate $4 \mathrm{~L} / \mathrm{min}$ through F0, F1, F2, and F3. The concentrations of chemical components such as $\mathrm{SO}_{4}{ }^{2-}, \mathrm{NO}_{3}{ }^{-}, \mathrm{Cl}^{-}, \mathrm{NH}_{4}^{+}, \mathrm{Ca}^{2+}, \mathrm{K}^{+}, \mathrm{Na}^{+}$, and $\mathrm{Mg}^{2+}$ were determined by using Ion Chromatograph. Chemical analyses of $\mathrm{NH}_{3}, \mathrm{HNO}_{3}, \mathrm{HCl}$, and $\mathrm{SO}_{2}$ were also measured by Ion Chromatography in the unit of ppb [12].

Monthly average wet deposition data for anions, $\mathrm{SO}_{4}{ }^{2-}$, $\mathrm{NO}_{3}{ }^{-}$, and $\mathrm{Cl}^{-}$(in $\mu \mathrm{mol} / \mathrm{L}$ ), and cations, $\mathrm{H}^{+}, \mathrm{NH}_{4}{ }^{+}, \mathrm{Ca}^{2+}, \mathrm{K}^{+}$, $\mathrm{Na}^{+}$, and $\mathrm{Mg}^{2+}$ (in $\mu \mathrm{mol} / \mathrm{L}$ ), were calculated for their seasonal averages: DJF (December-January-February); MAM (MarchApril-May); JJA (June-July-August); and SON (SeptemberOctober-November). The research objective was to study the factors that influence rainwater chemistry variability: seasons or pollutant sources in Medan $(3.62 \mathrm{~N} ; 98.62 \mathrm{E})$ as capital city of North Sumatera, Kototabang $(0.20 S$; 100.32E) as remote area in West Sumatera near Bukittinggi, Palembang (3S; 104.7E) as the capital city of South Sumatera, and Lampung (5.24S; 105.17E) as the capital city of Lampung Province in Sumatera. Figure 2 showed wet deposition monitoring locations and high fire risk of forest and land areas in Sumatera.

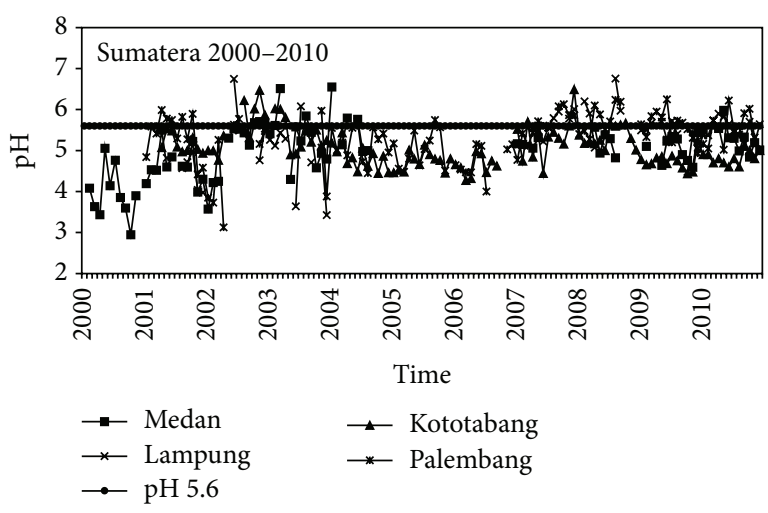

Figure 3: The temporal distribution of $\mathrm{pH}$ in Medan, Kototabang, Lampung, and Palembang (2000-2010).

\section{Result and Discussion}

3.1. Rainwater Acidity Trend. During 2000-2010 the $\mathrm{pH}$ value in Medan ranged from 3.57 to 6.55, Kototabang 4.27 to 6.48, Lampung 3.43 to 6.76, and Palembang 3.12 to 6.25 (Figure 3). The rainwater $\mathrm{pH}$ values distribution as the indicator of rainwater acidity was varied below and above 5.6 during 2000-2010. During 2000-2002, the rainwater $\mathrm{pH}$ values were below 5.6, but during 2002-2003 its values were above 5.6. They were then decreasing below 5.6 between 2004 and 2006 during the relatively big events of the forest fire. The worst forest fire occurred in 2006 [13]. According to the Ministry of Forest, about 11,306.40 ha of forest and land in 2006 and $6,544.75$ ha of forest and land in 2007 were destroyed $[14,15]$. In 2006 extreme draught occurred due to strong El Nino [16]. Kototabang, a suburb and remote area in Indonesia (with no anthropogenic activity) where Global Atmospheric Watch (GAW) is located, had relatively low rainwater $\mathrm{pH}$ value which was below 5.6 in 2010. A region is indicated to have suffered acid rain if its rainwater $\mathrm{pH}$ value is found below $5.6[4]$.

The cumulative frequency statistic analysis was carried out to obtain acid rain occurrence percentage with the rainwater $\mathrm{pH}$ value below 5.6 (Figure 4 ). The rainwater $\mathrm{pH}$ distribution during 2001-2010 showed that acid rain had occurred in Medan, Kototabang, Lampung, and Palembang with the cumulative frequency of $75.4 \%, 84.3 \%, 52.7 \%$, and $58.16 \%$, respectively. Kototabang as a remote area suffered from acid rain during those years. It indicated that dominant influences were acid elements or anions. Likewise, in Medan, a capital city of North Sumatera, the frequent occurrence of acid rain with the high percentage of occurrence was about $75.4 \%$. A big city with high transportation and industrial activities contributed to the relatively large amount of pollutants in the atmosphere such as $\mathrm{SO}_{2}$ and $\mathrm{NO}_{2}$. However in Lampung, where observation point was located in a suburb area Branti, acid rain occurrence percentage was 52.7\%, which was relatively lower than Medan and Kototabang. This condition showed that acid and base factors were equal in influencing rainwater acidity. The same condition was also found in Palembang where the acid rain occurrence 


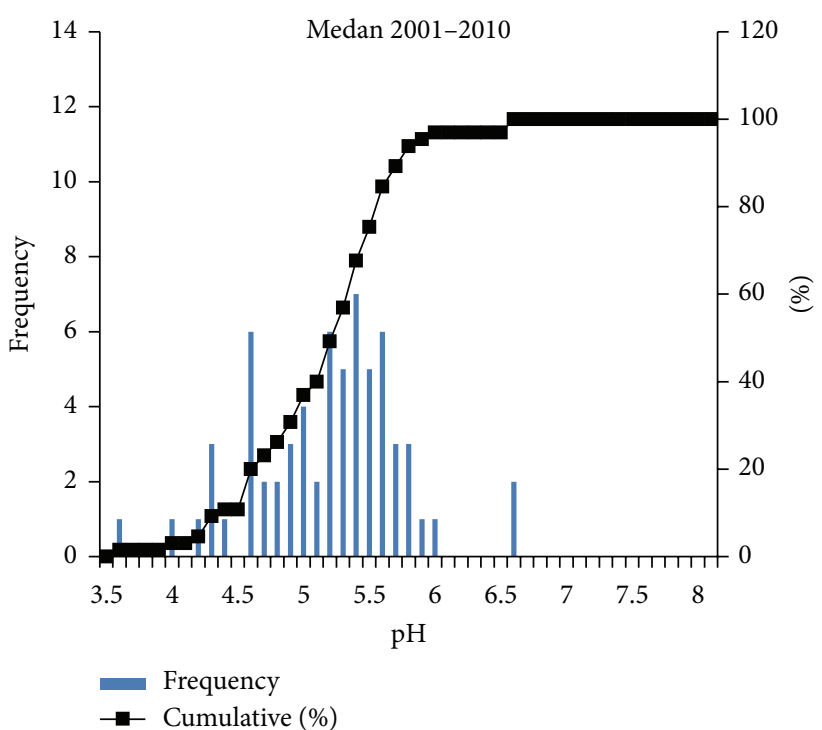

(a)

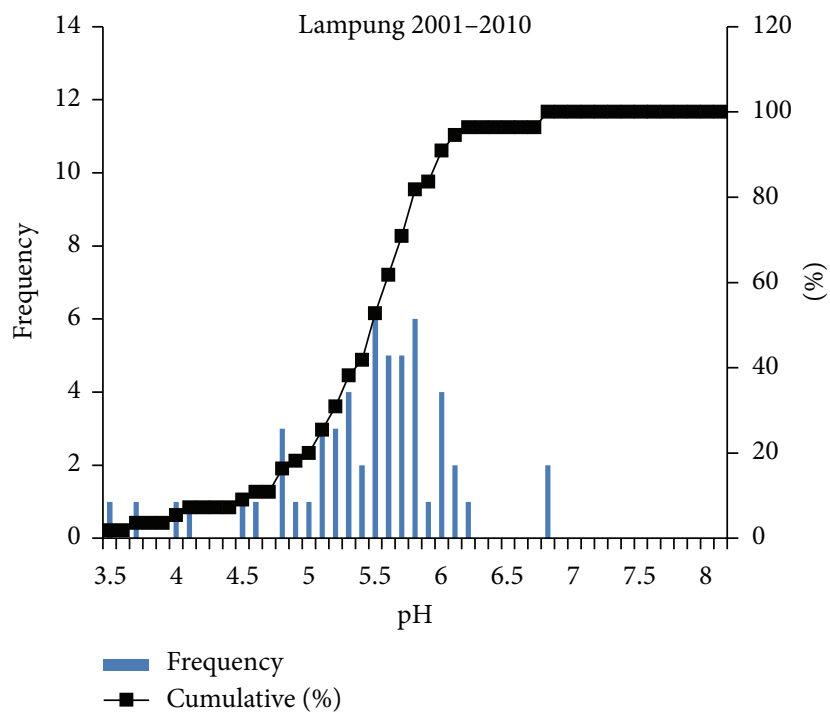

(c)

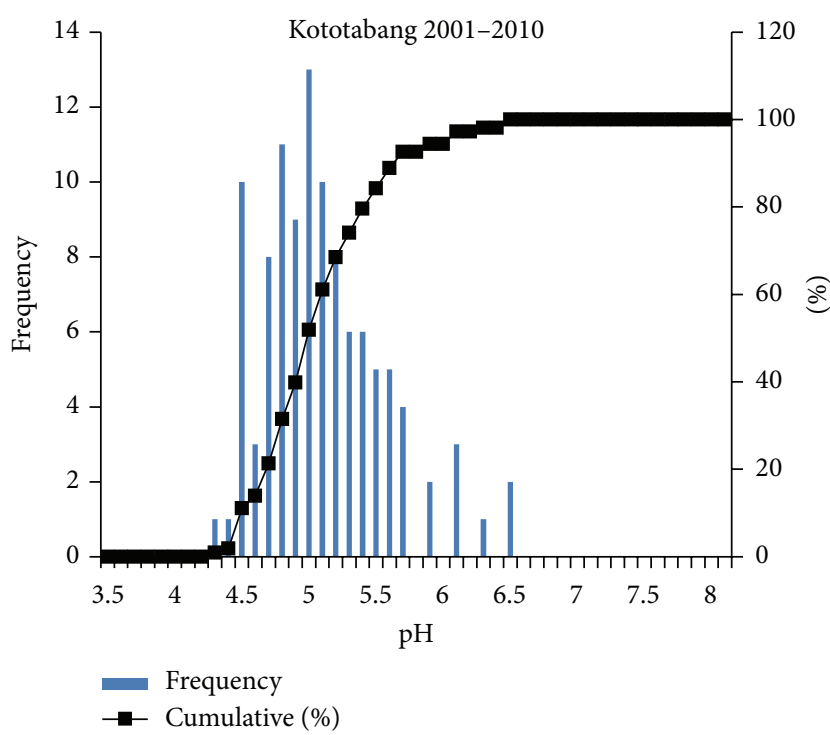

(b)

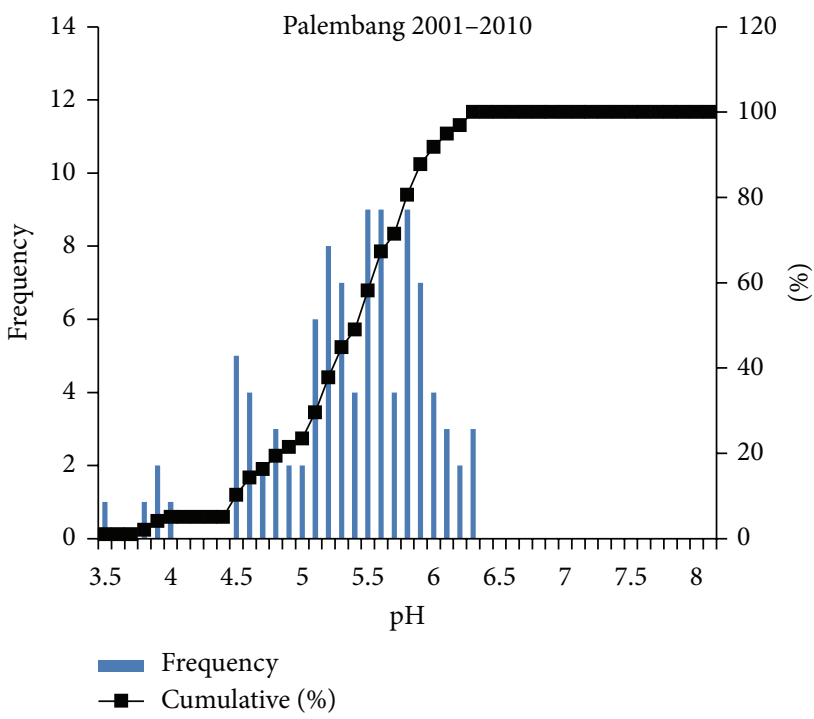

(d)

FIgURE 4: Rainwater $\mathrm{pH}$ distribution in four different cities in Indonesia.

percentage was $58.16 \%$. Rainwater chemistry was studied to find out which elements are dominating rainwater acidity in Sumatera.

3.2. Rainwater Chemical Composition Characteristics. Rainwater chemical composition characteristics or wet deposition described ammonium and chloride ions, both being the indicators of forest fires influence for the location that was far away from the coast, were higher than sulfate and nitrate (Figure 5). The conditions were found in Medan, Lampung, Palembang, and Kototabang. In areas close to the sea, sea salt is a major contributor to sodium and chloride deposition, and the molar $\mathrm{Na}^{+} / \mathrm{Cl}^{-}$ratio in precipitation is typically that of sea salt, namely, 0.86 [17]. Chloride ion $\left(\mathrm{Cl}^{-}\right)$was indicated as sea originated if the ratio value of $\mathrm{Na}^{+} / \mathrm{Cl}^{-}$was above 0.86 for coastal regions. However, sodium to chloride molar ratios measured along the entire profile $\left(\mathrm{Cl}^{-} / \mathrm{Na}^{+}\right.$mean value $=$ $1.137, s=0.008$ ) is very close to the bulk sea water value of 1.16 [17]. Average, $\mathrm{Cl}^{-} / \mathrm{Na}^{+}$ratio was very close to sea water value (1.16) indicating that $\mathrm{Cl}^{-}$was completely contributed by marine sources [18]. The average ratio values of $\mathrm{Cl}^{-} / \mathrm{Na}^{+}$ in Medan, Lampung, Palembang, and Kototabang during 2001-2010 were $1.49,1.16,1.30$, and 1.15 , respectively. The ratio values of $\mathrm{Na}^{+} / \mathrm{Cl}^{-}$in Medan, Lampung, Palembang, and Kototabang were $0.67,0.86,0.77$, and 0.87 , respectively. Dikaiakos et al. [19] found that $\mathrm{Na}^{+} / \mathrm{Cl}^{-}$value was 0.81 for $n=57$ samples, Grundahl 0.82 [20], and Brewer 0.86 [21]. Nevertheless, Medan and Palembang had ratio value less than 0.86. Lampung and Kototabang had $\mathrm{Cl}^{-}$value almost similar to $\mathrm{Na}^{+}$although they were located further from the sea. 


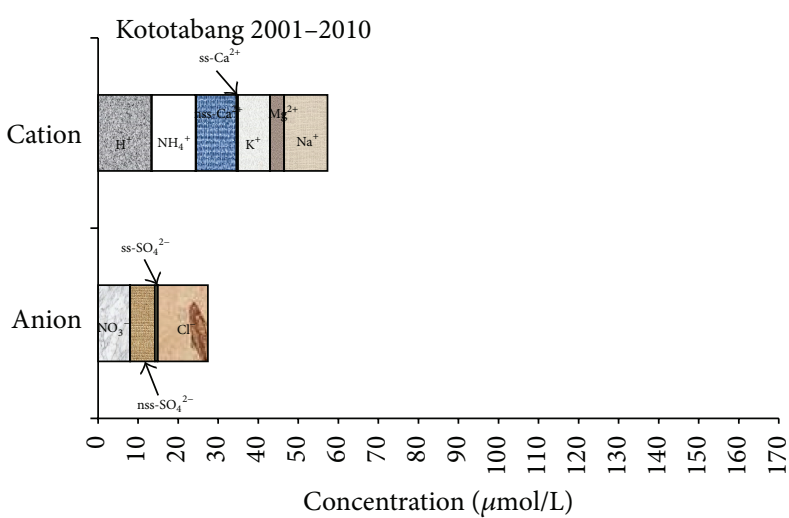

(a)

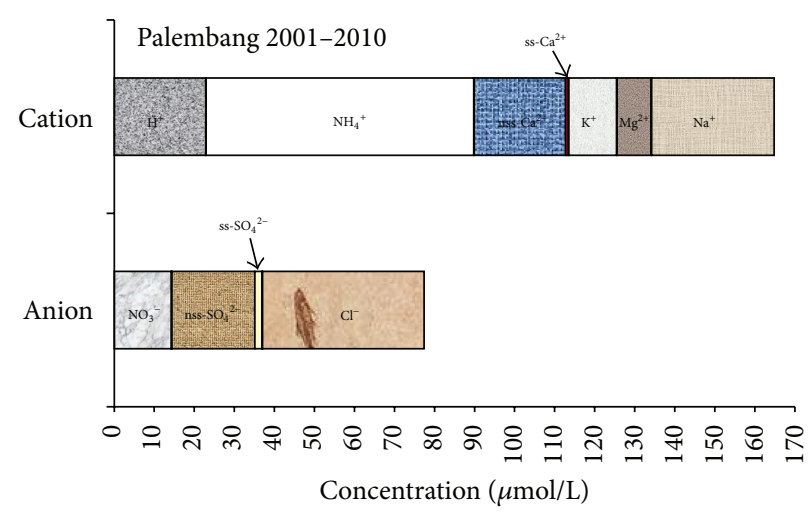

(c)

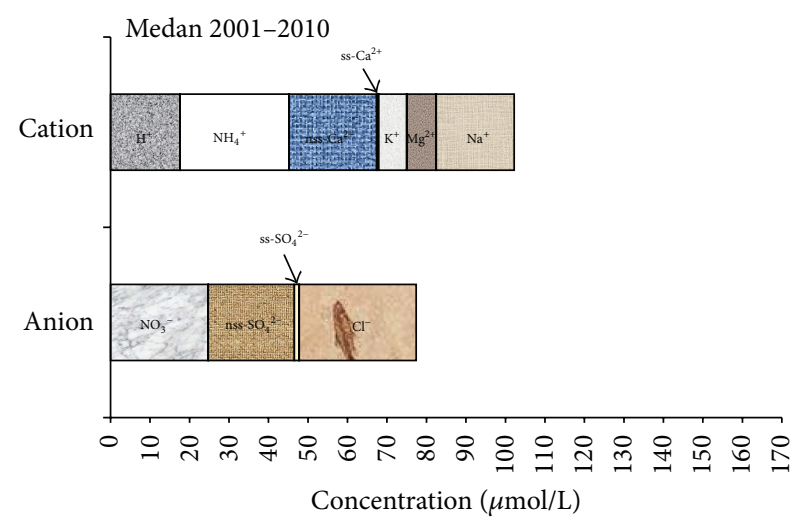

(b)

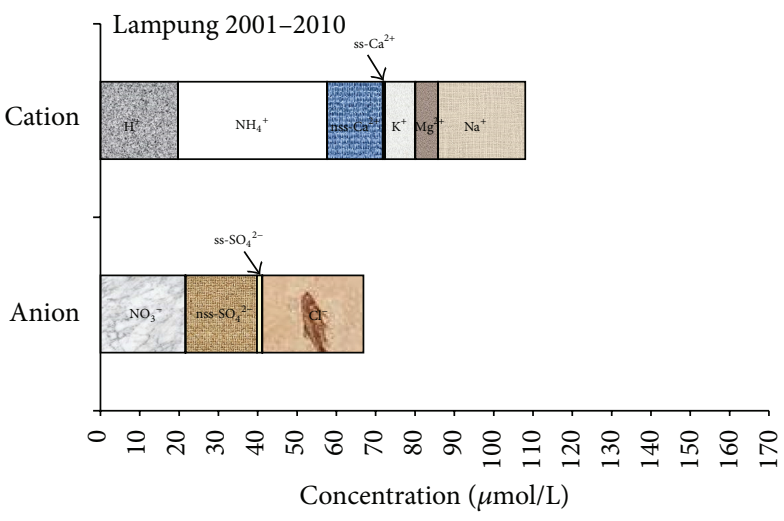

(d)

FIgURE 5: Rainwater chemical characteristics in Kototabang, Medan, Lampung, and Palembang.

Therefore, forest fires influence was observed in those two regions.

Ions composition from high to low concentrations for Medan was $\mathrm{Cl}^{-}>\mathrm{NH}_{4}{ }^{+}>\mathrm{NO}_{3}{ }^{-}>$nss- $\mathrm{Ca}^{2+}>$ nss- $\mathrm{SO}_{4}{ }^{2-}>$

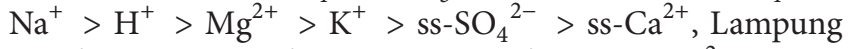
$\mathrm{NH}_{4}{ }^{+}>\mathrm{Cl}^{-}>\mathrm{Na}^{+}>\mathrm{NO}_{3}{ }^{-}>\mathrm{H}^{+}>\mathrm{nss}_{-} \mathrm{SO}_{4}{ }^{2-}>$ nss-

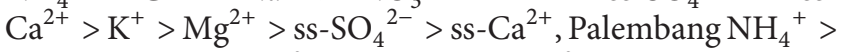
$\mathrm{Cl}^{-}>\mathrm{Na}^{+}>\mathrm{nss}^{-} \mathrm{Ca}^{2+}>\mathrm{H}^{+}>\mathrm{nss}^{2} \mathrm{SO}_{4}{ }^{2-}>\mathrm{NO}_{3}{ }^{-}>\mathrm{K}^{+}>$

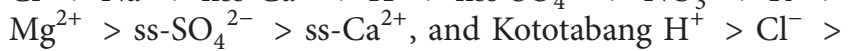
$\mathrm{Na}^{+}>\mathrm{NH}_{4}^{+}>\mathrm{nss}_{-} \mathrm{Ca}^{2+}>\mathrm{K}^{+}>\mathrm{NO}_{3}^{-}>\mathrm{nss}_{-} \mathrm{SO}_{4}{ }^{2-}>$ $\mathrm{Mg}^{2+}>\mathrm{ss}^{2} \mathrm{SO}_{4}{ }^{2-}>{\mathrm{ss}-\mathrm{Ca}^{2+}}^{2+}$ (Figure 5). The concentration levels classification showed that $\mathrm{Cl}^{-}$and $\mathrm{NH}_{4}{ }^{+}$were higher than $\mathrm{NO}_{3}{ }^{-}$and nss- $\mathrm{SO}_{4}{ }^{2-}$ in Medan, Lampung, Palembang, and Kototabang that indicated the influence of forest fires frequently occurred in Sumatera. Biomass burning released aerosol and also abundant gaseous $\mathrm{NO}_{x}, \mathrm{SO}_{2}, \mathrm{CH}_{3} \mathrm{Cl}$, and $\mathrm{CH}_{3} \mathrm{Br}$ to the atmosphere [22].

Air pollution dispersion depends on meteorology condition of its environment from one area to another because of the different source of activities. This behavior is potential to cause transboundary pollutant. Biomass burning produces fine and coarse particles, gases, and black carbon (BC) to the air. A study by Hooper [23] showed that particulate compositions in Kototabang from April 1996 to August 1999 contained high concentration of black carbon in their coarse and fine particles of $660 \mathrm{ng} / \mathrm{m}^{3}$ and $148 \mathrm{ng} / \mathrm{m}^{3}$, respectively. Black carbon and potassium in fine particles were both biomass burning indicators that lead to high carbon concentration $[23,24]$. The fine particles in Kototabang had high concentrations of potassium $(\mathrm{K})$ and black carbon for about $55 \mathrm{ng} / \mathrm{m}^{3}$ and $660 \mathrm{ng} / \mathrm{m}^{3}$, respectively. The relatively high concentrations of $\mathrm{Na}^{+}, \mathrm{Cl}^{-}$, and $\mathrm{Ca}^{2+}$ were also found: $97 \mathrm{ng} / \mathrm{m}^{3}, 59 \mathrm{ng} / \mathrm{m}^{3}$, and $33 \mathrm{ng} / \mathrm{m}^{3}$, respectively. Sulfur concentration in fine particles was also relatively high, for about $210 \mathrm{ng} / \mathrm{m}^{3}$. The highest concentrations of other elements were contained in fine and coarse particles [23].

Particle compositions had a high concentration of sulfur, $\mathrm{Na}, \mathrm{Cl}$, and $\mathrm{Ca}$ after black carbon and $\mathrm{K}$ [23]. Therefore, those elements influenced the wet deposition in Kototabang or other areas. Rainwater chemistry characteristic in Kototabang showed a high concentration of $\mathrm{Na}^{+}, \mathrm{Cl}^{-}, \mathrm{Ca}^{2+}$, and $\mathrm{K}^{+}$ although it was still below a concentration of $\mathrm{NH}_{4}{ }^{+}$. The high concentrations of $\mathrm{Na}^{+}$and $\mathrm{Cl}^{-}$in Kototabang were originated from particulate components produced by biomass burning or $\mathrm{Cl}^{-}$from volcanic gaseous $\mathrm{HCl}$ near to the monitoring location. They were supported by the fact that Kototabang was a remote area in a highland near Bukittinggi, but it was far away from sea mineral influence. This characteristic pattern was also found in Palembang and Lampung. The rainwater chemical characteristic similarity was also found in Medan 


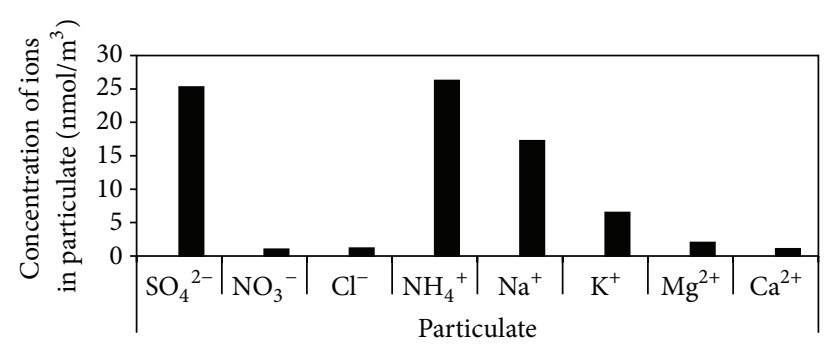

(a)

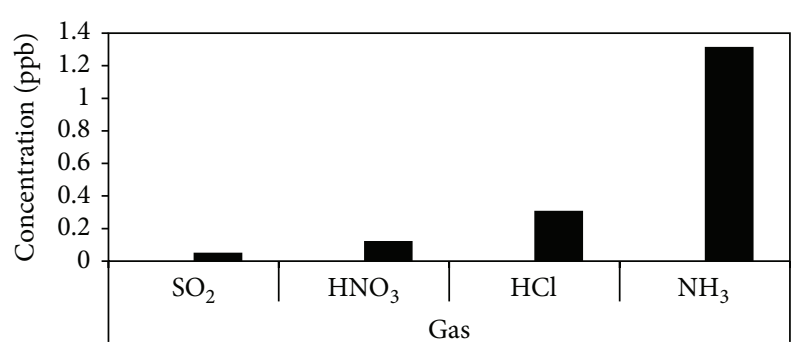

(b)

FIgure 6: (a) Particulate chemical composition and (b) $\mathrm{SO}_{2}, \mathrm{HNO}_{3}, \mathrm{HCl}$, and $\mathrm{NH}_{3}$ in Kototabang, Sumatera.
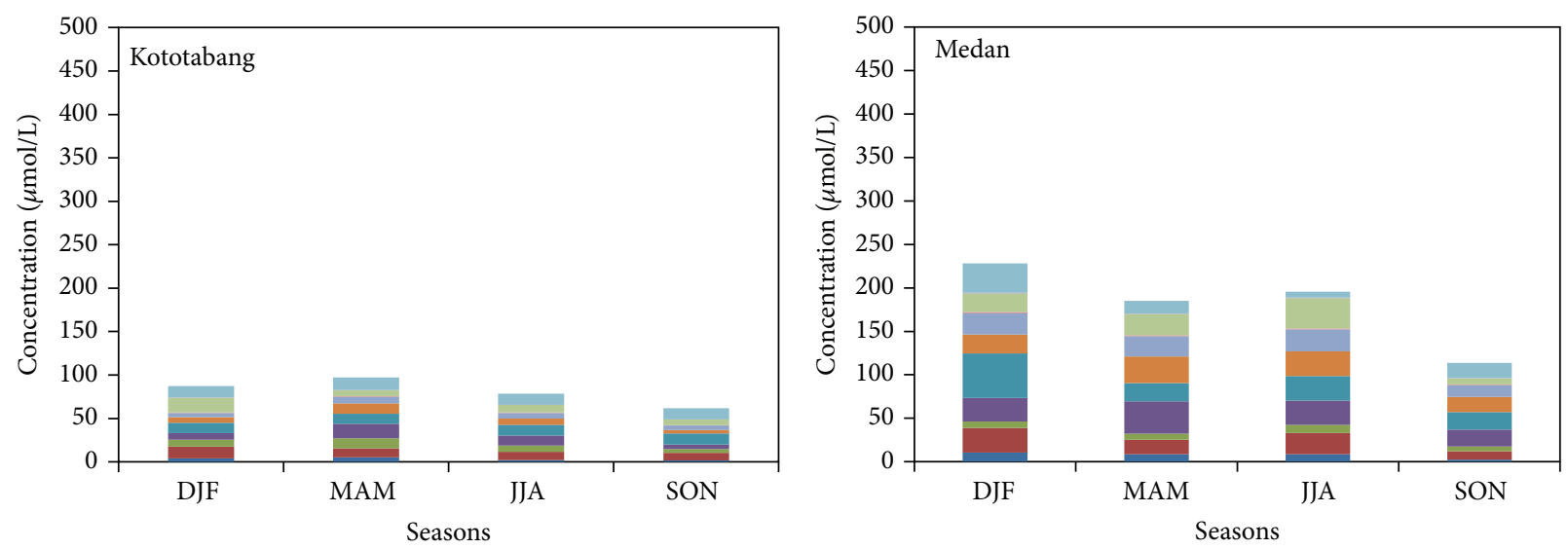

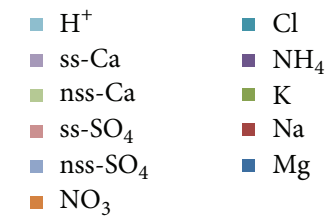

(a)

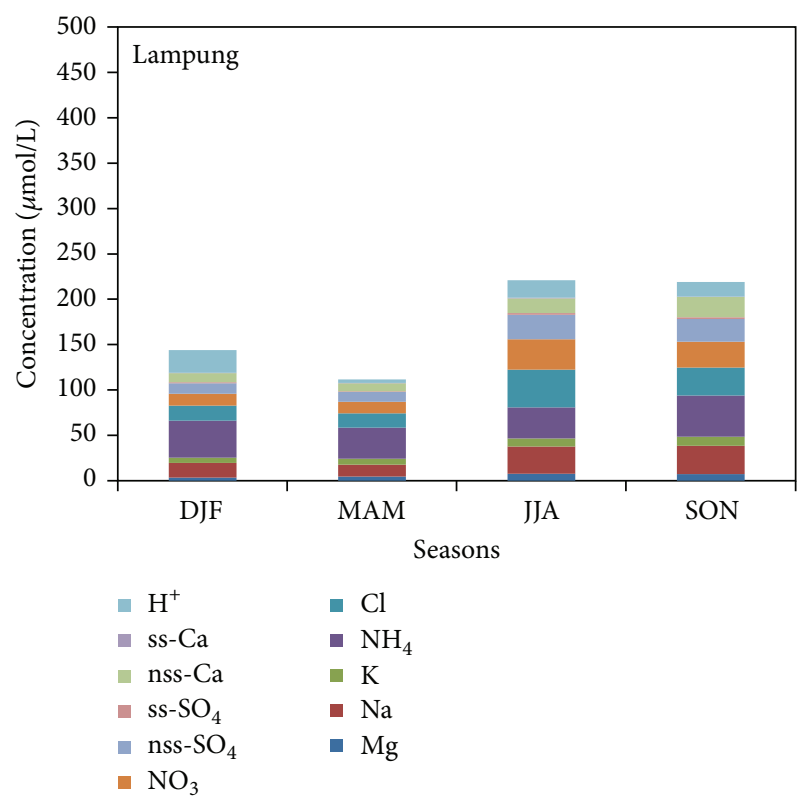

(c)

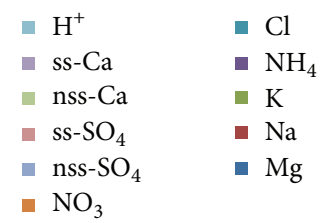

(b)

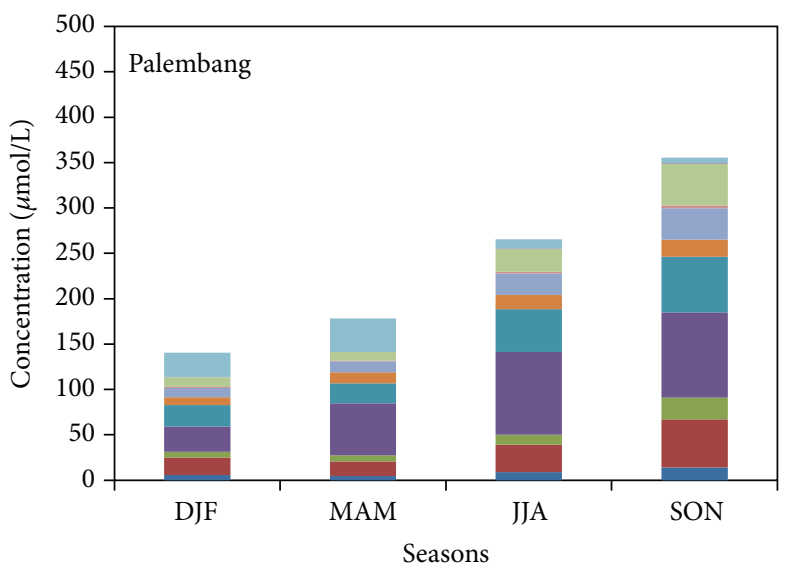

(d)

FIGURE 7: Seasonal rainwater chemical composition variability (in $\mu \mathrm{mol} / \mathrm{L}$ ) during DJF, MAM, JJA, and SON seasons for the period $2001-2010$ in four different cities in Indonesia. 


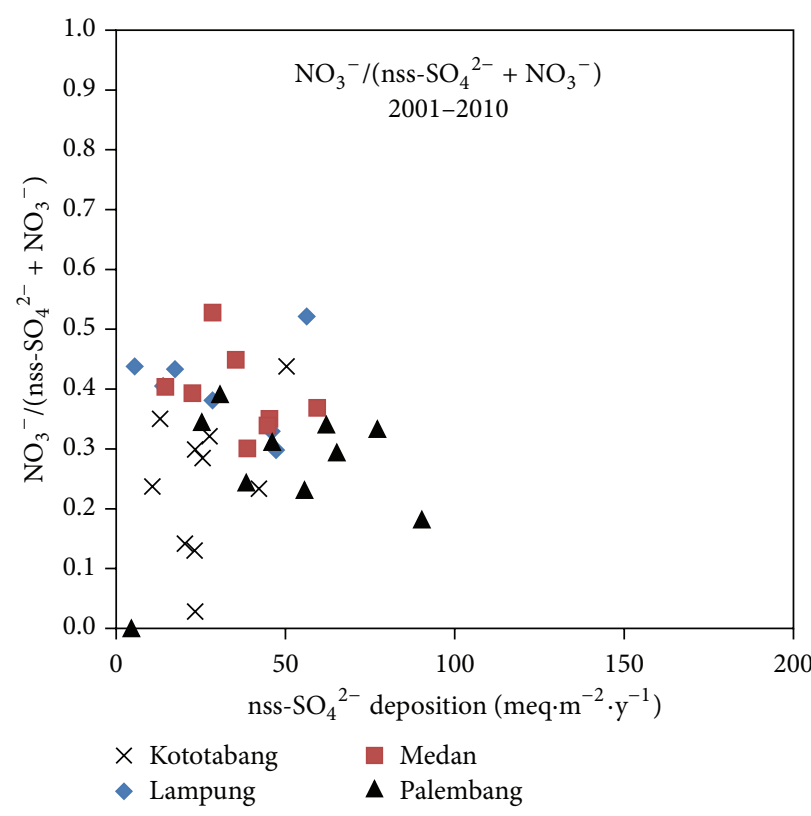

(a)

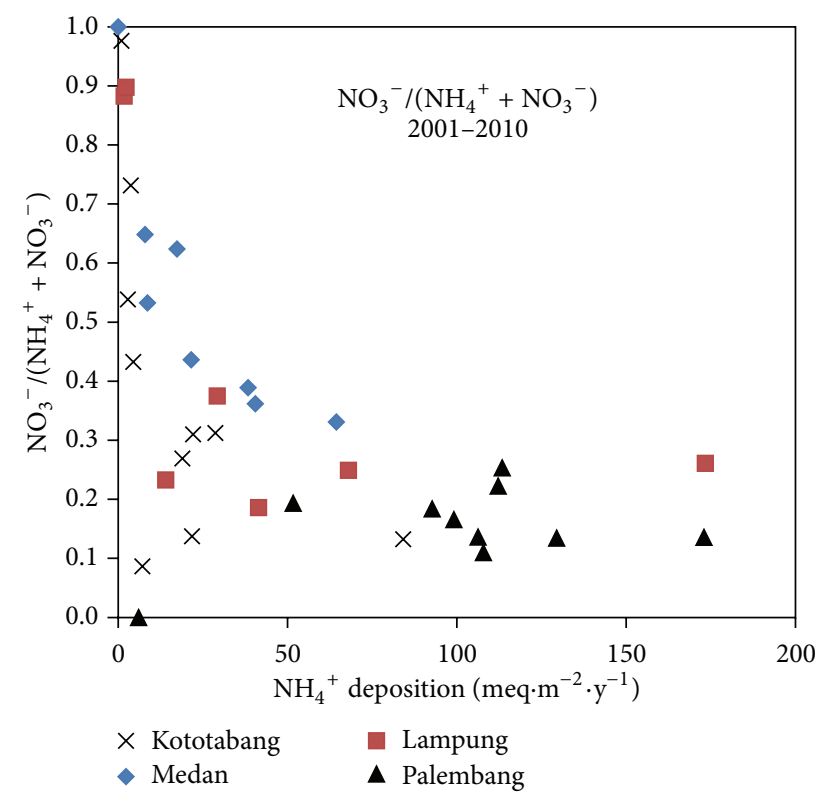

(b)

FIGURE 8: Relationships between annual depositions at the Sumatera sites: (a) nss- $\mathrm{SO}_{4}{ }^{2-}$ with ratio of $\mathrm{NO}_{3}{ }^{-} /\left(\mathrm{nss}^{-} \mathrm{SO}_{4}{ }^{2-}+\mathrm{NO}_{3}{ }^{-}\right)$and $(\mathrm{b})$ $\mathrm{NH}_{4}{ }^{+}$with ratio of $\mathrm{NO}_{3}{ }^{-} /\left(\mathrm{NH}_{4}{ }^{+}+\mathrm{NO}_{3}^{-}\right)$in $2001-2010$.

and Lampung, although the contents of nitrate and sulfate were higher for Medan and Lampung. Medan is a capital city of North Sumatera Province, where high traffic and industries numbers were observed. Moreover, Lampung is situated on a very busy Trans-Sumatera highway. Therefore anthropogenic impact showed a high concentration of sulfate and nitrate, especially in Medan and Lampung. Particle or particulate sulfur was produced by the conversion of $\mathrm{SO}_{2}$ to sulfate through the oxidation process, and it was homogenous. Only half of particulate sulfate was originated from a local source as there was no adequate time to convert into another form of compounds. Gas turned into fine particle would disperse far away from its source. Sulfur contained in fine particles could lead to transboundary pollutant issue depending on major source locations [25].

Based on analysis results of particulate samples during sampling by filter pack from September 21, 2012, to September 28, 2012, in Kototabang (Figure 6(a)), it was found that $\mathrm{NH}_{4}{ }^{+}$contents were the highest and then followed by $\mathrm{SO}_{4}{ }^{2-}$ : $\mathrm{Na}^{+}, \mathrm{K}^{+}$, and $\mathrm{Mg}^{2+}$ in descending order. This condition was appropriate with high sulfur content in fine particles according to Hooper [23]. High concentrations of $\mathrm{NH}_{4}{ }^{+}$and gaseous $\mathrm{NH}_{3}$ (Figure 6(b)) had contributed to ammonium contained in rainwater chemistry in Kototabang (Figure 5). Besides high concentration of gaseous $\mathrm{NH}_{3}$, it was also found that gaseous $\mathrm{HCl}$ concentration was higher than $\mathrm{HNO}_{3}$ and $\mathrm{SO}_{2}$. Kototabang is located at an altitude of $864 \mathrm{~m}$ above sea level and was close to the small forest and active volcano named Marapi. Removal of $\mathrm{NH}_{3}$ by cloud drop increased $\mathrm{pH}$ and "washout" of $\mathrm{SO}_{2}$ to form $\left(\mathrm{NH}_{4}\right)_{2} \mathrm{SO}_{4}$ [26].

Total anion concentrations $\left(\mathrm{SO}_{4}{ }^{2-}, \mathrm{NO}_{3}{ }^{-}\right.$, and $\left.\mathrm{Cl}^{-}\right)$and cations $\left(\mathrm{H}^{+}, \mathrm{NH}_{4}^{+}, \mathrm{Ca}^{2+}, \mathrm{K}^{+}, \mathrm{Na}^{+}\right.$, and $\left.\mathrm{Mg}^{2+}\right)$ were high during season SON and JJA for Lampung and Palembang (Figure 7). They were related to their influencing sources. High concentrations of ammonium and $\mathrm{Cl}^{-}$were significantly related to forest fire occurrence during dry seasons proceeding to transition dry to wet season. On the contrary, Medan had high concentrations of total anion and cation during season DJF, that is, $228.0 \mu \mathrm{mol} / \mathrm{L}$, but during the other seasons MAM and JJA the concentrations were almost similar, that is, $185.2 \mu \mathrm{mol} / \mathrm{L}$ and $195.5 \mu \mathrm{mol} / \mathrm{L}$, respectively, and SON, that is, $113.9 \mu \mathrm{mol} / \mathrm{L}$. High forest fire occurrence during February in Riau probably resulted in the accumulation of pollutant during February in Medan. An interesting fact was that Kototabang near Riau had almost similar high concentrations profile to Medan during DJF and MAM, that is, $90.3 \mu \mathrm{mol} / \mathrm{L}$ and $97.1 \mu \mathrm{mol} / \mathrm{L}$, respectively. During seasons JJA and SON Kototabang had lower total anion and cation values of $78.6 \mu \mathrm{mol} / \mathrm{L}$ and $61.9 \mu \mathrm{mol} / \mathrm{L}$, respectively, and there was no change in total anion and cation values. During the wet season (December to March) the wind direction was from North to West and carried pollutant from North where Riau Province was located. Frequent forest and land fires took place in Riau Province (Figure 2).

3.3. Comparison with Deposition of Ions. Acid rain occurred if rainwater $\mathrm{pH}$ was less than 5.6 and was dominated by acid compounds such as sulfate, nitrate, and chloride. The equivalent ratio of deposition of $\mathrm{NO}_{3}{ }^{-} /\left(\right.$nss- $\mathrm{SO}_{4}{ }^{2-}+\mathrm{NO}_{3}{ }^{-}$) was plotted against nss- $\mathrm{SO}_{4}{ }^{2-}$ deposition to show clear relationships between the deposition of $\mathrm{NO}_{3}{ }^{-}$and nss- $\mathrm{SO}_{4}{ }^{2-}$ (Figure 8(a)). The ratio of deposition of $\mathrm{NO}_{3}{ }^{-} /\left(\mathrm{NH}_{4}{ }^{+}+\mathrm{NO}_{3}{ }^{-}\right)$ was plotted with $\mathrm{NH}_{4}{ }^{+}$deposition to assess the relationships between the deposition of $\mathrm{NO}_{3}{ }^{-}$and $\mathrm{NH}_{4}{ }^{+}$(Figure 8(b)). 
TABLE 1: Rainfall, $\mathrm{pH}$ (rainwater acidity), comparative ratio between annual depositions of $\mathrm{NO}_{3}{ }^{-} /\left(\mathrm{nss}_{-} \mathrm{SO}_{4}{ }^{2-}+\mathrm{NO}_{3}{ }^{-}\right)$with nss-SO ${ }^{2-}$ and $\mathrm{NO}_{3}{ }^{-} /\left(\mathrm{NH}_{4}{ }^{+}+\mathrm{NO}_{3}{ }^{-}\right)$with $\mathrm{NH}_{4}{ }^{+}$, and also comparative ratio between depositions of $\mathrm{Na}^{+}$with $\mathrm{Cl}^{-}$. Unit of the ion depositions in $\mathrm{meq} \cdot \mathrm{m}^{-2} \cdot \mathrm{y}^{-1}$.

\begin{tabular}{|c|c|c|c|c|c|c|}
\hline Location & Year & Rainfall (mm) & $\begin{array}{c}\mathrm{NO}_{3}{ }^{-} /\left(\mathrm{nss}_{-} \mathrm{SO}_{4}{ }^{2-}+\right. \\
\left.\mathrm{NO}_{3}{ }^{-}\right)\end{array}$ & $\begin{array}{c}\mathrm{NO}_{3}{ }^{-} /\left(\mathrm{NH}_{4}{ }^{+}+\right. \\
\left.\mathrm{NO}_{3}^{-}\right)^{-}\end{array}$ & $\mathrm{pH}$ & $\mathrm{Cl}^{-} / \mathrm{Na}^{+}$ \\
\hline \multirow{10}{*}{ Kototabang } & 2001 & 1209 & 0.24 & 0.54 & 5.16 & 1.46 \\
\hline & 2002 & 1798 & 0.28 & 0.73 & 5.56 & 2.66 \\
\hline & 2003 & 3127 & 0.44 & 0.98 & 5.39 & 2.88 \\
\hline & 2004 & 2405 & 0.30 & 0.31 & 4.83 & 1.32 \\
\hline & 2005 & 2287 & 0.13 & 0.14 & 4.73 & 1.27 \\
\hline & 2006 & 1248 & 0.32 & 0.31 & 4.62 & 0.38 \\
\hline & 2007 & 3430 & 0.23 & 0.13 & 5.33 & 1.30 \\
\hline & 2008 & 2481 & 0.35 & 0.27 & 5.33 & 0.73 \\
\hline & 2009 & 2656 & 0.03 & 0.09 & 4.73 & 1.75 \\
\hline & 2010 & 2064 & 0.14 & 0.43 & 4.97 & 1.33 \\
\hline \multirow{10}{*}{ Medan } & 2001 & 2106 & 0.53 & 0.33 & 4.63 & 1.59 \\
\hline & 2002 & 1342 & 0.45 & 0.62 & 5.09 & 2.77 \\
\hline & 2003 & 1765 & 0.37 & 1.00 & 5.29 & 3.97 \\
\hline & 2004 & 345 & 0.39 & 0.65 & 5.81 & 1.95 \\
\hline & $2005^{*}$ & & & & & \\
\hline & $2006^{*}$ & & & & & \\
\hline & 2007 & 528 & 0.40 & 0.53 & 5.17 & 1.54 \\
\hline & 2008 & 645 & 0.30 & 0.44 & 5.20 & 1.13 \\
\hline & 2009 & 1239 & 0.35 & 0.39 & 5.03 & 1.62 \\
\hline & 2010 & 1209 & 0.34 & 0.36 & 5.30 & 1.15 \\
\hline \multirow{10}{*}{ Lampung } & 2001 & 452 & 0.44 & 0.23 & 4.52 & 1.35 \\
\hline & 2002 & 529 & 0.43 & 0.88 & 5.63 & 1.39 \\
\hline & 2003 & 1453 & 0.30 & 0.90 & 4.89 & 2.43 \\
\hline & $2004^{*}$ & & & & & \\
\hline & $2005^{*}$ & & & & & \\
\hline & $2006^{*}$ & & & & & \\
\hline & 2007 & 757 & 0.38 & 0.37 & 5.68 & 1.29 \\
\hline & 2008 & 630 & 0.41 & 0.19 & 5.98 & 0.78 \\
\hline & 2009 & 1821 & 0.33 & 0.25 & 5.39 & 1.03 \\
\hline & 2010 & 2390 & 0.35 & 0.26 & 5.55 & 0.96 \\
\hline \multirow{10}{*}{ Palembang } & 2001 & 2100 & 0.39 & 0.17 & 5.39 & 1.16 \\
\hline & 2002 & 1701 & 0.33 & 0.25 & 4.75 & 1.88 \\
\hline & $2003^{*}$ & & & & & \\
\hline & 2004 & 1566 & 0.23 & 0.14 & 5.19 & 1.11 \\
\hline & 2005 & 2004 & 0.31 & 0.18 & 5.02 & 1.37 \\
\hline & 2006 & 1654 & 0.24 & 0.19 & 4.73 & 1.69 \\
\hline & 2007 & 2267 & 0.34 & 0.22 & 5.59 & 2.03 \\
\hline & 2008 & 1153 & 0.34 & 0.11 & 5.75 & 0.95 \\
\hline & 2009 & 2317 & 0.18 & 0.13 & 5.60 & 1.78 \\
\hline & 2010 & 3470 & 0.29 & 0.14 & 5.49 & 1.07 \\
\hline
\end{tabular}

Note: $*$ : no sampling of rainwater in Medan, Palembang, and Lampung. 


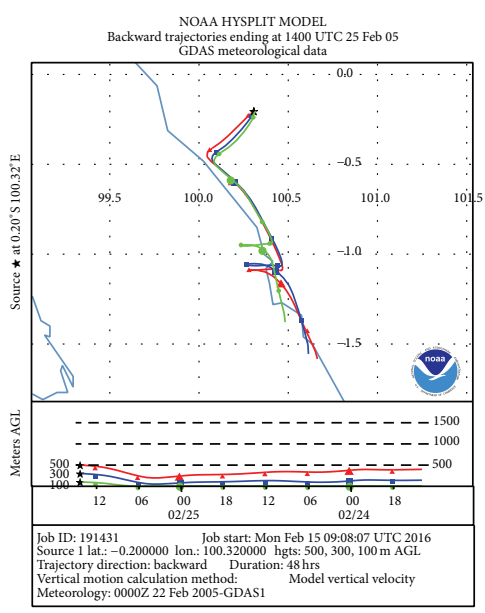

(a)

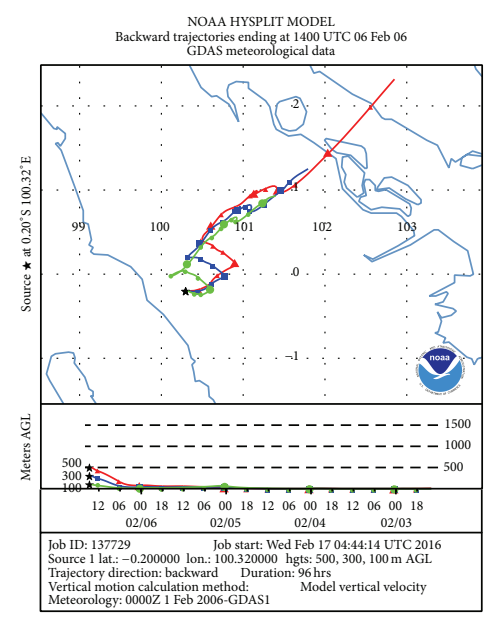

(c)

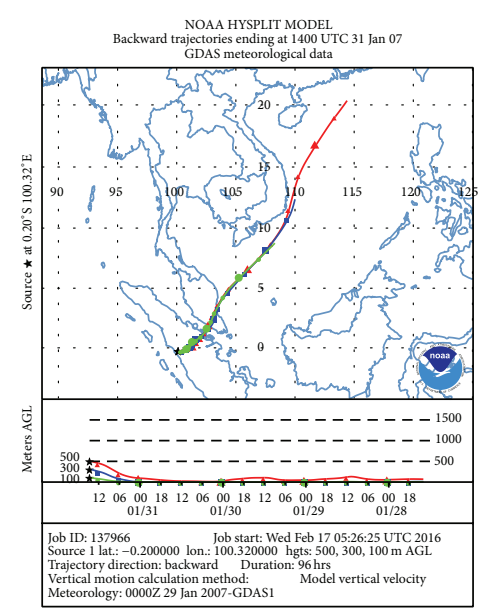

(e)

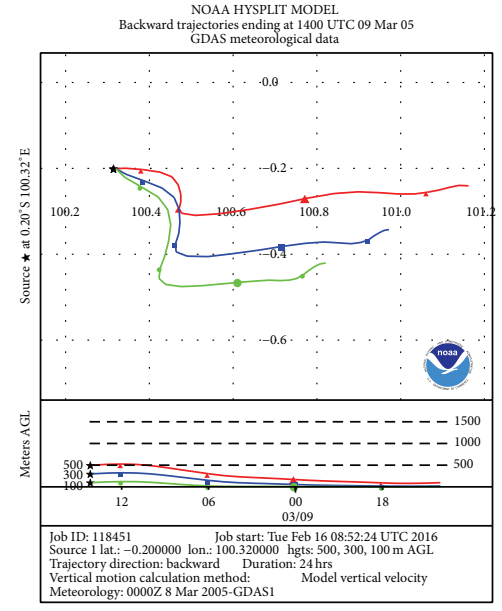

(b)

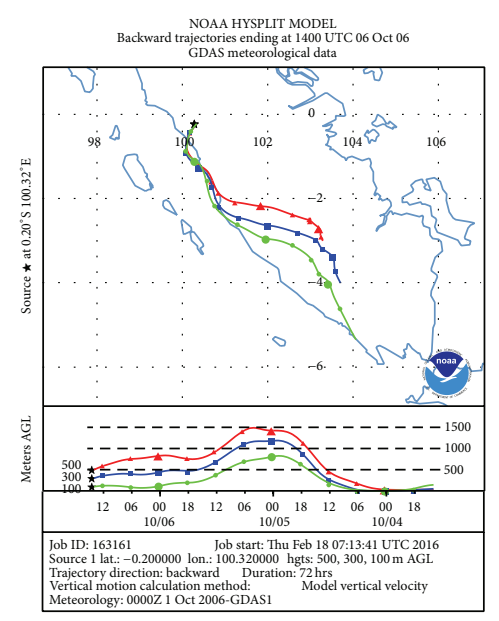

(d)

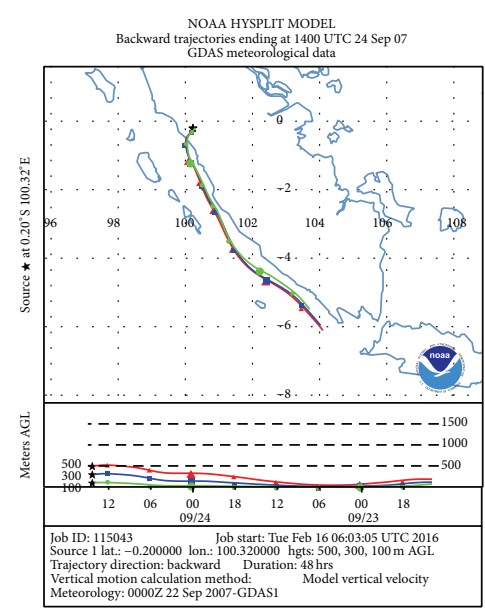

(f)

FIGURE 9: Examples of six different air mass trajectories arriving in Kototabang during fire event for wet and dry seasons in 2005, 2006, and 2007. Date and the origin of air mass trajectories: (a) Feb 24, 2005, fires and smoke in Sumatera; (b) March 9, 2005, fires and smoke in Sumatera; (c) Feb 3, 2006, fires in Southeast Asia; (d) Oct 4, 2006, fires in Sumatera; (e) January 28, 2007, fires in Southeast Asia; (f) Sep 23, 2007, fires in Sumatera. 
Table 1 showed the ratio of deposition $\mathrm{Cl}^{-} / \mathrm{Na}^{+}$. If the value of $\mathrm{NO}_{3}{ }^{-} /\left(\mathrm{nss}-\mathrm{SO}_{4}{ }^{2-}+\mathrm{NO}_{3}{ }^{-}\right)<0.5$ then nss-SO ${ }_{4}{ }^{2-}$ was higher than $\mathrm{NO}_{3}{ }^{-}$. During 2001 to 2010 frequency value of $\mathrm{NO}_{3}{ }^{-} /\left(\right.$nss- $\left.\mathrm{SO}_{4}{ }^{2-}+\mathrm{NO}_{3}{ }^{-}\right)<0.5$ was $97 \%$ from 34 annual mean pieces of data in Medan, Kototabang, Lampung, and Palembang. Kototabang, Palembang, and Lampung showed more dominant influence of forest fire than anthropogenic, except Medan. It was indicated by higher ammonium content than $\mathrm{NO}_{3}{ }^{-}$if the ratio value of $\mathrm{NO}_{3}{ }^{-} /\left(\mathrm{NH}_{4}{ }^{+}+\mathrm{NO}_{3}{ }^{-}\right)<$ 0.5 was $62 \%$. Ammonium content indicated by frequency values of $\mathrm{NO}_{3}{ }^{-} /\left(\mathrm{NH}_{4}{ }^{+}+\mathrm{NO}_{3}{ }^{-}\right)<0.5$ was $74 \%$ of total 34 annual mean pieces of data in four locations, that is, Medan, Kototabang, Palembang, and Lampung. The deposition of nss- $\mathrm{SO}_{4}{ }^{2-}$ and $\mathrm{NH}_{4}{ }^{+}$was higher than $\mathrm{NO}_{3}{ }^{-}$. Chloride also had higher concentration than sodium $\left(\mathrm{Na}^{+}\right.$originated from the sea) with a frequency value of deposition ratio $\mathrm{Cl}^{-} / \mathrm{Na}^{+}$in the range of $0.25-2.65$.

3.4. Air Mass Trajectories. HYSPLIT (Hybrid Single Particle Lagrangian Integrated Trajectory) model had been carried out to get air mass trajectories. We used a web based system called READY (real-time environmental applications and display) system developed by the Air Resources Laboratory (ARL) [27]. READY is also used to run trajectory (for multiple source locations or one source location) and dispersion model assessment and display for meteorological data $[18,28]$. The HYSPLIT is the most widely used model and particulate matter is the kind of pollutant most frequently investigated. Backward trajectories of HYSPLIT are the most commonly calculated type [29].

HYSPLIT trajectory model with normal trajectory type was run to indicate a source of fire haze and smoke affecting air quality in Kototabang. Six examples of back trajectories within $500 \mathrm{~m}, 300 \mathrm{~m}$, and $100 \mathrm{~m}$ heights during dry and wet seasons showed particles arriving in Kototabang during forest and land fires events (Figure 9). Based on the back trajectories (Figures 9(a) and 9(b)) the origin of air mass was from the southern part of Sumatera, that is, Jambi Province and Riau Province, respectively. The particles arrived in sampling location in Kototabang in 1-2 days. Image of fire and smoke in Sumatera can be seen in a website of Earth ObservatoryNASA [31]. During February and March 2005 there were large forest and land fires releasing a large amount of smoke and haze to the atmosphere. Fires burning across the island of Sumatera produced a significant amount of pollutants in February 2005. Because carbon monoxide is the product of incomplete combustion of biomass burning therefore the gas is a good tracer of fire-induced pollution [31]. The highest concentrations of carbon monoxide at an altitude of roughly 3 kilometers (700 millibar) in the atmosphere over Kototabang was 168.75 ppbv [31].

Forest and land fires frequently occur during January, February, and March in the north of the equator such as in Thailand, Cambodia, and Vietnam. On the contrary, in the south of the equator such as Indonesia dry season occurs in August, September, and October when many forests and land fires occur. Regions in Indonesia where frequent forest and land fires take place were southern part of Sumatera such as Jambi Province, South Sumatera Province (Palembang), Lampung Province (Lampung), and Kalimantan [30]. During February 3, 2006, and January 28, 2007, air mass originated from forest fires in Southeast Asia arrived in Kototabang within 4 days (Figures 9(c) and 9(e)). On the other hand, on October 4, 2006, and September 23, 2007, air mass originated from the large forest fire in Sumatera reached Kototabang in 4 days (Figures 9(d) and 9(f)). Smoke emitted by forest fire led to high rainwater chemical composition in Kototabang during March, April, and May and also in Palembang and Lampung during September, October, and November (Figure 7).

\section{Conclusion}

It was proved that there was already transboundary pollutant from forest fire location to remote area (Kototabang). Effect of forest fires can be seen from the high ammonia content compared with the nitrates. It was indicated by a high concentration of ammonium and often occurs with a frequency value of the ratio of $\mathrm{NO}_{3}{ }^{-} /\left(\mathrm{NH}_{4}{ }^{+}+\mathrm{NO}_{3}{ }^{-}\right)<0.5$ being $74 \%$ of annual mean of 34 pieces of data. Chloride was more dominant than sodium $\left(\mathrm{Na}^{+}\right.$originated from the sea) with frequency value of deposition ratio $\mathrm{Cl}^{-} / \mathrm{Na}^{+}$being in the range of 0.25-2.65. Forest fire sources in Sumatera (Jambi Province, Riau Province, North Sumatera Province, and South Sumatera Province) had influenced acid deposition. Gaseous $\mathrm{NH}_{3}$ or $\mathrm{NO}_{2}$ and $\mathrm{SO}_{2}$ as the product of biomass burning contributed to acid deposition in Sumatera. Acid rain with $\mathrm{pH}<5.6$ ( $\mathrm{pH}=5.6$ was a limit to acid rain) had already occurred in Medan, Kototabang, Lampung, and Palembang with the percentage of $75.4 \%, 84.3 \%, 52.7 \%$, and $58.16 \%$, respectively, from total rain events during 2001-2010.

\section{Competing Interests}

The authors declare that they have no competing interests.

\section{Acknowledgments}

The authors wish to thank the Center for Atmospheric Science and Technology of Indonesian National Institute of Aeronautics and Space (LAPAN, Indonesia) and Agency for Meteorology, Climatology and Geophysics (BMKG, Indonesia) for permission to use rainwater chemical data. They also wish to thank ARL (Air Resources Laboratory) NOAA and Allen Jesse from Earth Observatory-NASA.

\section{References}

[1] U. C. Kulshrestha, M. J. Kulshrestha, R. Sekar, G. S. R. Sastry, and M. Vairamani, "Chemical characteristics of rainwater at an urban site of south-central India," Atmospheric Environment, vol. 37, no. 21, pp. 3019-3026, 2003.

[2] A. C. Stern, R. W. Boubel, D. B. Turner, and L. N. Fox, Fundamentals of Air Pollution, Academic Press, Orlando, Fla, USA, 2nd edition, 1984. 
[3] A. Milukaité, A. Mikelinskiené, and B. Giedraitis, "Characteristics of $\mathrm{So}_{2}, \mathrm{No}_{2}$, soot and benzo(a)pyrene concentration variation on the Eastern coast of the Baltic sea," in Proceedings of the 6th International Conference on Acidic Deposition: Looking back to the Past and Thinking of the Future, vol. 3, pp. 1553-1558, Tsukuba, Japan, December 2000.

[4] J. H. Seinfeld and S. N. Pandis, Atmospheric Chemistry and Physics from Air Pollution to Climate Change, John Wiley \& Sons, New York, NY, USA, 1998.

[5] E. Meszaros, Atmospheric Chemistry, Fundamental Aspects, Studies in Environmental Science II, Elsevier, 1981.

[6] M. Aikawa, T. Ohara, T. Hiraki et al., "Significant geographic gradients in particulate sulfate over Japan determined from multiple-site measurements and a chemical transport model: impacts of transboundary pollution from the Asian continent," Atmospheric Environment, vol. 44, no. 3, pp. 381-391, 2010.

[7] P. C. Mouli, S. V. Mohan, and S. J. Reddy, "Rainwater chemistry at a regional representative urban site: influence of terrestrial sources on ionic composition," Atmospheric Environment, vol. 39, pp. 999-1008, 2005.

[8] T. Budiwati, W. Setyawati, and A. Indrawati, "Analisis Tingkat Keasaman Dan Komposisi Kimia Air Hujan Sebagai Dampak Kebakaran Hutan di Pontianak (KALBAR)," in Proceedings of the Seminar Nasional Sains Atmosfer-Antariksa (SNSAA '12), p. LAPAN, 2012.

[9] U. Scholz, The Natural Regions of Sumatra and Their Agricultural Production Pattern, vol. 1\&2, Central Research Institute for Food Crops, Bogor, Indonesia, 1983.

[10] EANET, “Technical documents for wet deposition monitoring in East Asia," in Proceedings of the Second Interim Scientific Advisory Group Meeting of Acid Deposition Monitoring Network in East Asia, 2001.

[11] EANET, Textbook Data Reporting, Data Quality Assessment and Data Treatment of Wet Deposition Monitoring for EANET, The Network Center for Acid Deposition Monitoring Network in East Asia, 2002.

[12] EANET, "Technical document for filter pack method in East Asia," in Proceedings of the 3rd Session of the Science Advisory Committee (SAC '03), Pattaya, Thailand, November 2003.

[13] Ministry of Environment, State of Environment Report in Indonesia 2006, The State Ministry of Environment-Indonesia, Jakarta, Indonesia, 2007.

[14] KNLH, Status Lingkungan Hidup Indonesia 2007, Kementerian Negara Lingkungan Hidup, Jakarta, Indonesia, 2008.

[15] W. Setyawati and T. Budiwati, "Peningkatan konsentrasi karbon monoksida pada saat kebakaran hutan tahun 2006 di Indonesia," in Proceedings of the Seminar Nasional Kimia ke XVIII, FMIPA UGM, Yogyakarta, Indonesia, 2008.

[16] NOAA, ENSO Cycle: Recent Evolution, Current Status and Prediction, 2013, http://www.cpc.ncep.noaa.gov/products/analysis_monitoring/lanina/enso_evolution-status-fcsts-web.pdf.

[17] W. C. Keene, A. A. P. Pszenny, J. N. Galloway, and M. E. Hawley, "Sea-salt corrections and interpretation of constituent ratios in marine precipitation," Journal of Geophysical Research, vol. 91, no. 6, pp. 6647-6658, 1986.

[18] B. Kumar, S. Singh, G. P. Gupta, F. A. Lone, and U. C. Kulshrestha, "Long range transport and wet deposition fluxes of major chemical species in snow at Gulmarg in North Western Himalayas (India)," Aerosol and Air Quality Research, vol. 16, no. 3, pp. 606-617, 2016.
[19] J. G. Dikaiakos, C. G. Tsitouris, P. A. Siskos, D. A. Melissos, and P. Nastos, "Rainwater composition in Athens, Greece," Atmospheric Environment B, vol. 24, no. 1, pp. 171-176, 1990.

[20] L. Grundahl and K. Keiding, "Model for quality control of precipitation analysis," in Proceedings of the Workshop: "Measurement of Atmospheric Acidity", Commission of the European Communities, Montelibretti, Italy, June 1985.

[21] P. G. Brewer, "Minor elements in sea water," in Chemical Oceanography, vol. 1, p. 417, Academic Press, New York, NY, USA, 1975.

[22] N. J. Blake, D. R. Blake, B. C. Sive et al., "Biomass burning emissions and vertical distribution of atmospheric methyl halides and other reduced carbon gases in the South Atlantic region," Journal of Geophysical Research: Atmospheres, vol. 101, no. 19, pp. 24151-24164, 1996.

[23] M. Hooper, "Comparative study of regional aerosol in tropical Australia and Indonesia," in Proceedings of the 7th International Joint Seminar on the Regional Deposition Processes in the Atmosphere, pp. 36-43, Tsukuba, Japan, November 2001.

[24] M. Santoso, P. K. Hopke, A. Hidayat, and L. Diah Dwiana, "Sources identification of the atmospheric aerosol at urban and suburban sites in Indonesia by positive matrix factorization," Science of the Total Environment, vol. 397, no. 1-3, pp. 229-237, 2008.

[25] P. K. Hopke, D. D. Cohen, B. A. Begum et al., "Urban air quality in the Asian region," Science of the Total Environment, vol. 404, no. 1, pp. 103-112, 2008.

[26] W. A. H. Asman and A. J. Janssen, "A long-range transport model for ammonia and ammonium for Europe," Atmospheric Environment (1967), vol. 21, no. 10, pp. 2099-2119, 1987.

[27] ARL (Air Resources Laboratory) NOAA, 2016, https://ready .arl.noaa.gov/HYSPLIT.php.

[28] U. Kulshrestha and B. Kumar, "Airmass trajectories and long range transport of pollutants: review of wet deposition scenario in South Asia," Advances in Meteorology, vol. 2014, Article ID 596041, 14 pages, 2014.

[29] I. A. Pérez, F. Artuso, M. Mahmud, U. Kulshrestha, M. L. Sánchez, and M. Á. García, "Applications of air mass trajectories," Advances in Meteorology, vol. 2015, Article ID 284213, 20 pages, 2015.

[30] Earth Observatory-NASA, 2016, http://www.earthobservatory .nasa.gov/NaturalHazards/category.php?cat_id $=8 \& \mathrm{~m}=0 \& \mathrm{y}=2006$.

[31] J. Allen, NASA Image Using Data Provided Courtesy of the NCAR and University of Toronto MOPITT Teams, NASA Earth Observatory, 2005. 

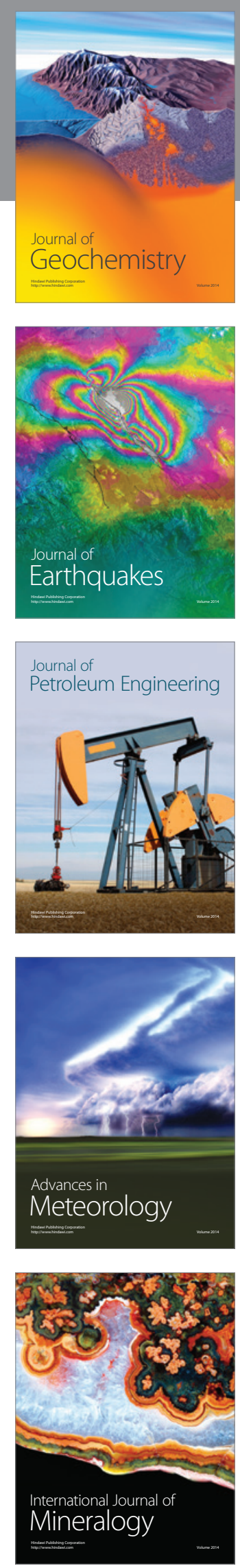
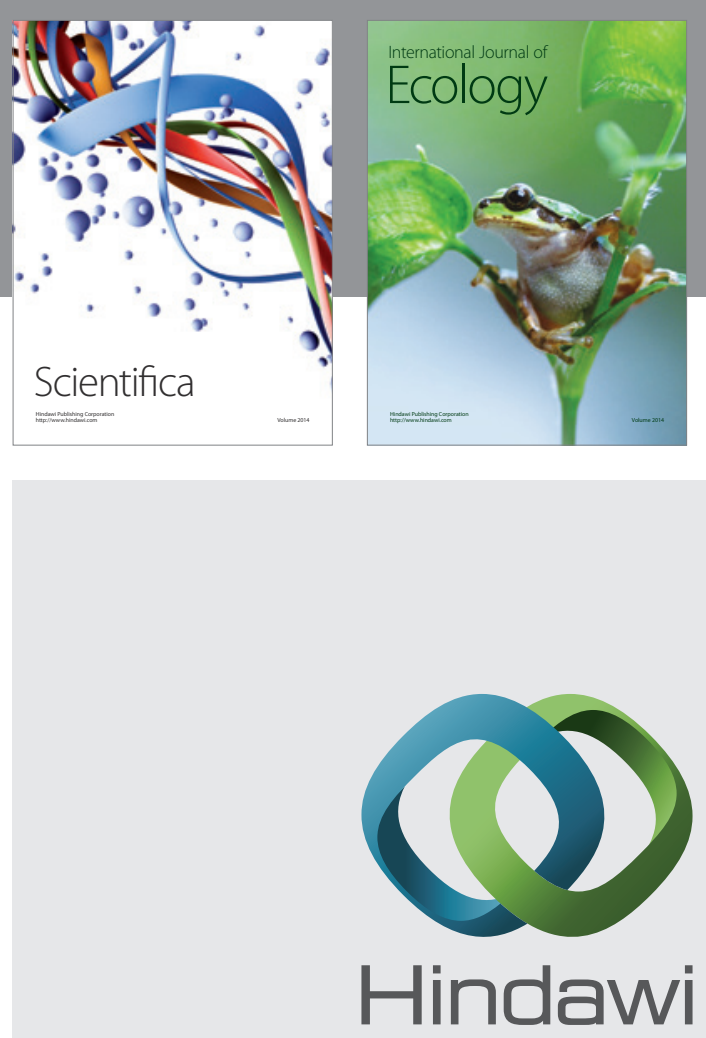

Submit your manuscripts at

http://www.hindawi.com
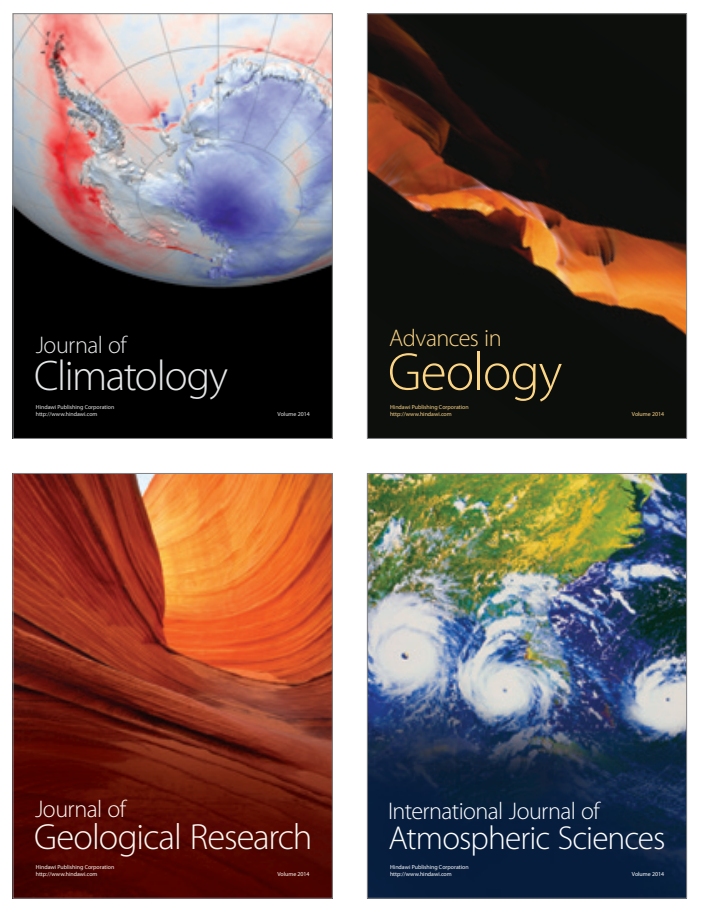

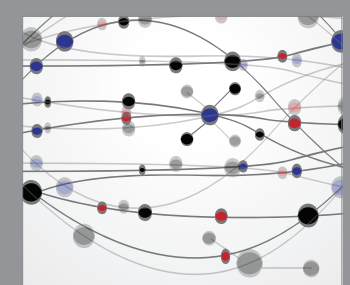

The Scientific

\section{World Journal}
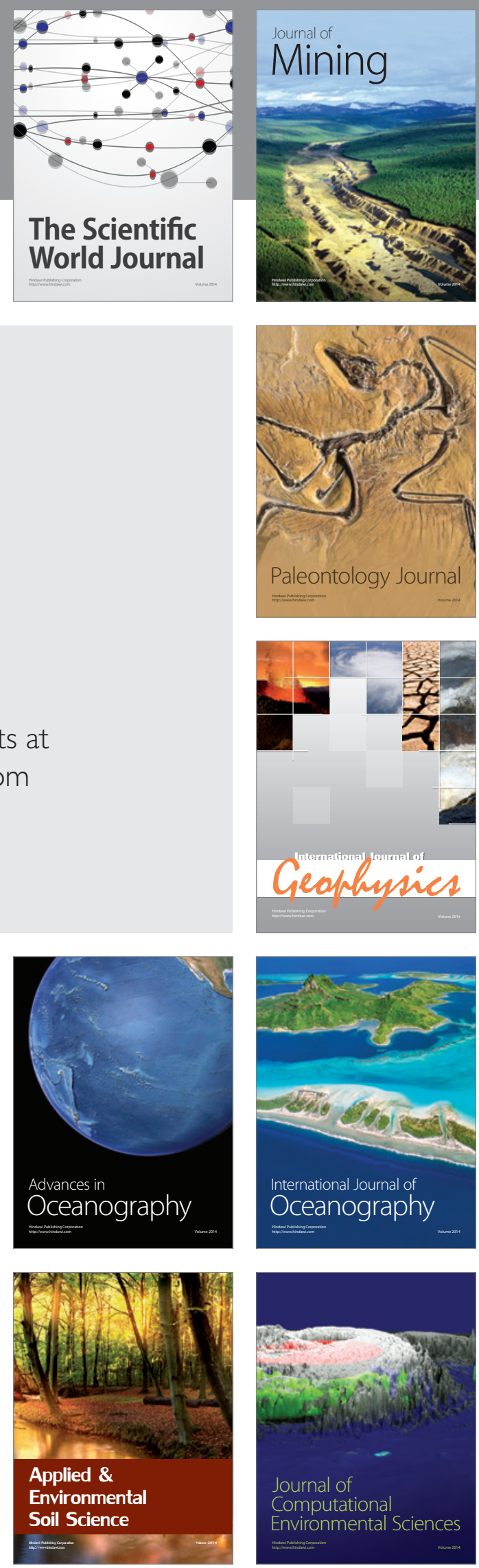